\section{Smith ScholarWorks}

\section{Paleosalinity History of Middle Holocene Lagoonal and Lacustrine Deposits in the Enriquillo Valley, Dominican Republic Based on Pore Morphometrics and Isotope Geochemistry of Ostracoda}

\author{
Pamela Medley \\ University of Mary Washington \\ Neil E. Tibert \\ University of Mary Washington \\ William P. Patterson \\ University of Saskatchewan \\ H. Allen Curran \\ Smith College, acurran@smith.edu \\ Lisa Greer \\ Washington and Lee University
}

See next page for additional authors

Follow this and additional works at: https://scholarworks.smith.edu/geo_facpubs

Part of the Geology Commons

\footnotetext{
Recommended Citation

Medley, Pamela; Tibert, Neil E.; Patterson, William P.; Curran, H. Allen; Greer, Lisa; and Colin, Jean-Paul, "Paleosalinity History of Middle Holocene Lagoonal and Lacustrine Deposits in the Enriquillo Valley, Dominican Republic Based on Pore Morphometrics and Isotope Geochemistry of Ostracoda" (2007). Geosciences: Faculty Publications, Smith College, Northampton, MA.

https://scholarworks.smith.edu/geo_facpubs/48
} 
Authors

Pamela Medley, Neil E. Tibert, William P. Patterson, H. Allen Curran, Lisa Greer, and Jean-Paul Colin

This article is available at Smith ScholarWorks: https://scholarworks.smith.edu/geo_facpubs/48 


\title{
Paleosalinity history of middle Holocene lagoonal and lacustrine deposits in the Enriquillo Valley, Dominican Republic based on pore morphometrics and isotope geochemistry of ostracoda
}

\author{
Pamela Medley ${ }^{1}$, Neil E. Tibert ${ }^{1 *}$, William P. Patterson ${ }^{2}$, \\ H. Allen Curran ${ }^{3}$, Lisa Greer ${ }^{4}$, Jean-Paul Colin ${ }^{5}$ \\ ${ }^{1}$ Department of Environmental Science \& Geology, University of Mary Washington, Fredericksburg VA, 22401, USA \\ ${ }^{2}$ Saskatchewan Isotope Laboratory, Department of Geological Sciences, University of Saskatchewan, \\ 114 Science Place, Saskatoon, SK S7N 5E2 Canada \\ ${ }^{3}$ Department of Geology, Smith College, Northampton MA,01063, USA \\ ${ }^{4}$ Department of Geology, Washington and Lee University, Lexington VA, 24450 USA \\ ${ }^{5}$ Impasse des Biroulayres, 33610 Cestas, France \\ *corresponding author: ntibert@umw.edu
}

\begin{abstract}
The southwestern region of the Dominican Republic (Enriquillo Valley) contains exceptionally well-preserved, relict marine and saline lake deposits of mid-Holocne age. Abundant euryhaline ostracodes found in this deposit include Cyprideis salebrosa, C. mexicana, C. similis, and C. edentata. Morphometric and geochemical analyses performed on Cyprideis spp. provide high $\delta^{18} \mathrm{O}$ and $\delta^{13} \mathrm{C}$ values that are coincident with relative abundances of irregularly shaped pores that permeate the ostracode carapace. We recognize three stratigraphic intervals with distinct ostracode pore shape and stable isotope trends: (I) a 4.5-5.0m interval that contains ostracodes with highly irregular shaped pores (multiradiate) and high amplitude variability in $\delta^{18} \mathrm{O}$ and $\delta^{13} \mathrm{C}$ values; (II) a 5.0-5.6m interval comprised of ostracodes with circular pores and an overall trend towards low $\delta^{18} \mathrm{O}$ and $\delta^{13} \mathrm{C}$ values; and (III) a 5.6-6.5m interval containing ostracodes with an upward increasing abundance of circular pore shapes coincident with decreasing $\delta^{18} \mathrm{O}$ and $\delta^{13} \mathrm{C}$ values. When the Enriquillo lagoon was first separated from the Caribbean Sea approximately $4.3 \mathrm{ka}$, an arid and evaporative climate led to hypersaline water in a restricted lagoon environment. By the middle to late-Holocene, increased precipitation in the valley resulted in a coastal lake system that became progressively oligohaline. Moderate to small amplitude variability in the salinity proxy data $\left(\delta^{18} \mathrm{O}\right)$ suggest short-term oscillations in the precipitation-evaporation budgets at that time. At least two marine incursions likely contributed to the observed variability in ostracode $\delta^{18} \mathrm{O}$ and $\delta^{13} \mathrm{C}$ values. Evidence for abrupt changes in base level indicate that climatic factors or also tectonic activity may have contributed to the observed paleoenvironmental trends recorded in these deposits.
\end{abstract}

\section{INTRODUCTION}

Enriquillo Valley displays well-preserved deposits of early-to middle Holocene coral crest, patch, and back reef deposits. Before $5 \mathrm{ka}$, the valley was an extension of the Caribbean Sea where a healthy fringing coral reef thrived until flood plain and alluvial deposits choked the mouth of the valley and separated the lagoon from the sea (Mann et al. 1984; Taylor et al. 1985). Resulting reef deposits contain abundant skeletal material that is ideally suited to create paleoenvironmental paleohydrology histories (Greer and Swart 2006).

The hydrology of the modern Enriquillo Valley is complicated by basin hypsography and tectonism in the Caribbean region (Mann et al. 1984). Because salinity and isotope ratios can vary independently, we employ a multi-proxy approach using ostracode pore morphometrics coupled with carapace stable isotope geochemistry that permits differentiation between salinity and temperature driven isotope variability. Our approach can facilitate paleohydrological reconstructions such that distinction between hyposalinity $(0<34 \%$ ) and hypersalinity $(>34 \% 0)$ in ancient deposits is possible (Gliozzi and Mazzini 1998; Mazzini et al 1999; Anadon et al. 2002). More specifically, within the restricted Enriquillo basin, external sieve pores on the ostracode Cyprideis salebrosa, deposited in restricted lagoonal-to-lacus-

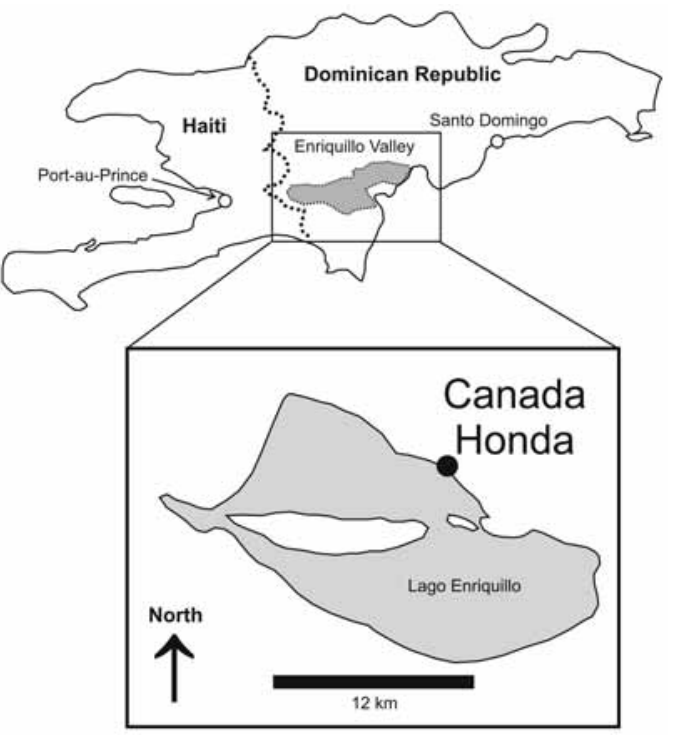

TEXT-FIGURE 1

Index map to the island of Hispañola with the Dominican Republic (east) and Haiti (west). Inset shows Lago Enriquillo and the study site at Canada Honda. 


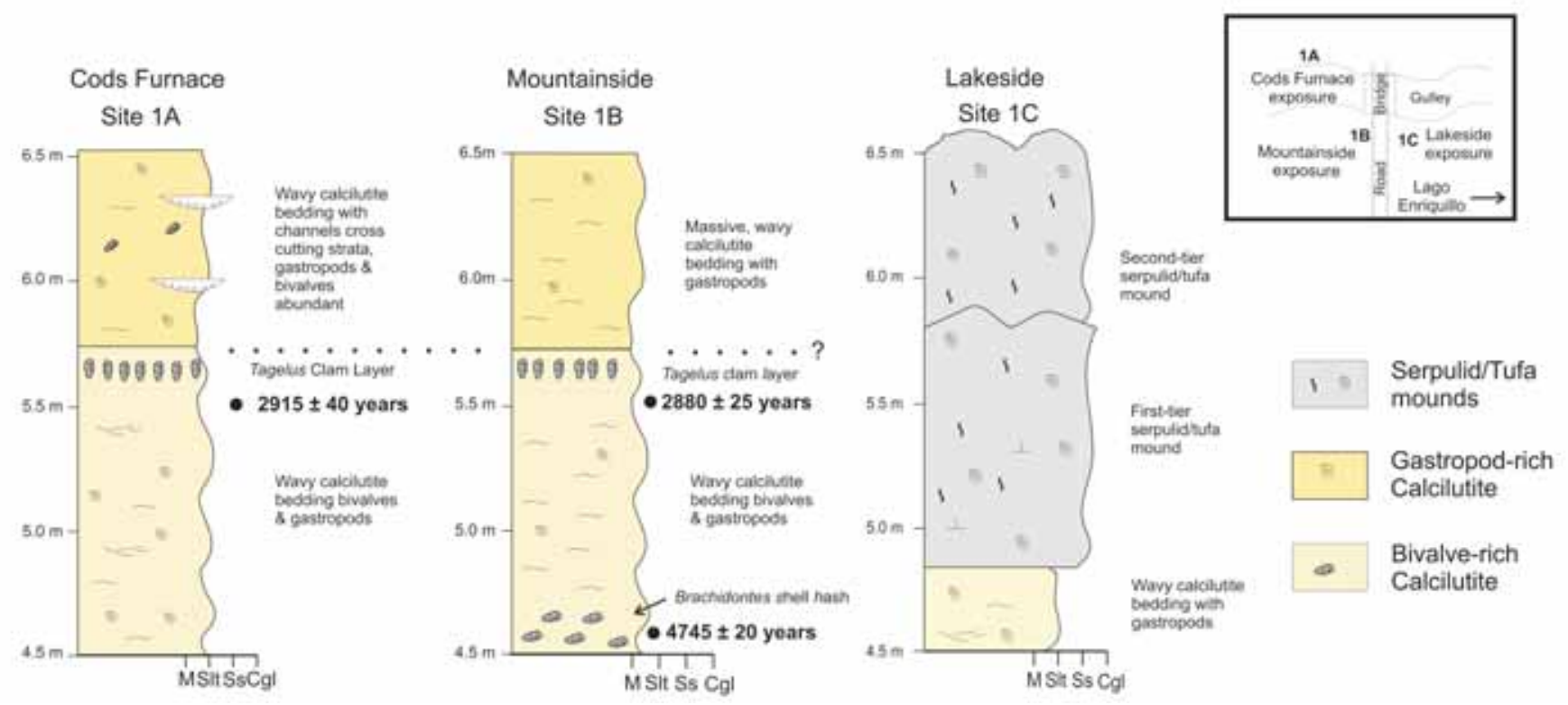

TEXT-FIGURE 2

Three laterally equivalent subsections of Unit 3; Sites 1A, 1B, and 1C. Sections 1A and 1B were correlated based on the Tagelus plebius razor clam layer at $5.6 \mathrm{~m}$. Sites 1A and 1B were correlated with site 1C based on the last occurrence of exclusively stenohaline Bairdidae and Trachyleberidae ostracodes and the appearance of the euryhaline Cyprideis salebrosa. Site $1 \mathrm{~A}$ was subjected to rigorous ostracode pore morphometrical analyses. AMS ${ }^{14} \mathrm{C}$ were obtained from: (1) Brachiodontes sp. analyzed at $4.6 \mathrm{~m} \sim 4745 \pm 20$ years; and (2) Tagelus plebius analyzed at $5.6 \mathrm{~m} \sim 2915 \pm 40$ years. Note that these dates are uncorrected for hard-water effects.

trine deposits (Bold 1990), were characterized in terms of circularity.

Rosenfeld and Vesper (1977) demonstrated that Cyprideis shows a positive relationship between irregularity of pore shape and increased salinity of water. Holocene marsh deposits from Spain have complicated and highly variable geochemical signals attributed to mixing of different source waters, (e.g., meteoric, riverine, marine) (Gliozzi and Mazzini 1998; Anadon et al. 2002). To confirm freshwater influence in the Spanish marsh deposits, the relative abundances of circular normal pores on Cyprideis torosa were used as indicators for oligohaline condi-

TABLE 1

Pore morphometric measurements for each stratigraphic height.

\begin{tabular}{ccc}
\hline $\begin{array}{c}\text { Stratigraphic } \\
\text { Height }\end{array}$ & $\begin{array}{c}\text { Number of } \\
\text { Specimens }\end{array}$ & $\begin{array}{c}\text { Number of } \\
\text { Measurements } \\
\text { per specimen }\end{array}$ \\
\hline 4.5 & 2 & 50,45 \\
4.7 & 4 & $41,12,12,26$ \\
4.8 & 1 & 16 \\
5.0 & 1 & 36 \\
5.2 & 1 & 11 \\
5.3 & 2 & 14,20 \\
5.4 & 2 & 4,9 \\
5.6 & 1 & 19 \\
5.7 & 3 & $21,23,12$ \\
5.9 & 2 & 21,19 \\
6.0 & 3 & $28,28,35$ \\
6.1 & 1 & 26 \\
6.2 & 2 & 11,6
\end{tabular}

tions (Gliozzi and Mazzini 1998; Anadon et al. 2002). Carbonnel (1983) performed detailed morphometric studies using the ostracode Cyprideis torosa from Alicante, Spain, and recognized three similar distinct morphotypes of the taxon associated with marine, hyposaline, and hypersaline conditions. Carbonnel and Haj-Chahine (2002) applied pore morphometric techniques to Miocene Cyprideis pannonica collected from restricted lake deposits in Lebanon. These authors attributed the observed increase in pore irregularity to hypersaline conditions forced by arid climatic conditions. These studies highlight the potential for pore morphometric analysis to enhance or refine geochemical and paleohydrological models in marginal marine basins.

Our primary objectives in this study include: (1) an evaluation of the relationship between ostracode pore shape and $\delta^{18} \mathrm{O}$ and $\delta^{13} \mathrm{C}$ values to develop a paleosalinity model based on the original model proposed by Rosenfeld and Vesper (1977); and (2) development of a high-resolution paleosalinity history for the middle to late-Holocene strata deposited in the Enriquillo Valley of the Dominican Republic ( 5-3 kyr before present).

\section{LOCATION AND GEOLOGIC SETTING}

The Dominican Republic is located in the central Caribbean on the island of Hispañola. The Cañada Honda study site is located the north side of Lago Enriquillo, the modern-day hypersaline lake in the Enriquillo Valley (18 $31^{\prime}$ '57.4' ' $\mathrm{N}$ and $71^{\circ} 37^{\prime}$ $5.8^{\prime \prime} \mathrm{W}$ ) (text-fig. 1). Outcrop exposures of this study are comprised of Holocene reef and lagoonal/lacustrine deposits found in gullies and road cuts adjacent to the modern lake.

The Dominican Republic is tectonically active and exhibits northwest to southeast-striking mountain chains that are separated by extensive valleys (Lewis et al 1990). The Enriquillo Valley is nested between the Neiba and Baoruco Mountains, 
TABLE 2

Summary table of the range in pore sizes, range in circularity values, and oxygen and carbon isotopes.

\begin{tabular}{ccccccc}
\hline $\begin{array}{c}\text { Strat. Hgt }(\mathbf{m}) \\
\text { (Site 1A) }\end{array}$ & $\begin{array}{c}\text { Range } \\
\text { Area } \\
(\boldsymbol{\mu m})\end{array}$ & $\begin{array}{c}\text { Range } \\
\text { Circularity }\end{array}$ & Pore Slope & $\begin{array}{c}\text { Pore } \\
\text { Shape }\end{array}$ & $\delta^{\mathbf{1 8}} \mathbf{O}$ & $\delta^{\mathbf{1 3}} \mathbf{C}$ \\
\hline 4.5 & $50-175$ & $0.2-0.5$ & -0.002 & irregular & 0.8 & -2.28 \\
4.6 & no data & no data & no data & no data & 0.85 & -2.11 \\
4.7 & $25-200$ & $0.4-0.9$ & $5.00 \mathrm{E}-05$ & $\begin{array}{c}\text { elongated } \\
\text { irregular }\end{array}$ & -0.85 & -5.05 \\
4.8 & $50-125$ & $0.3-0.85$ & -0.0039 & 0.42 & -2.88 \\
4.9 & $50-150$ & $0.6-0.95$ & 0.0002 & round & -1.23 & -2.63 \\
5.0 & $50-160$ & $0.6-0.95$ & -0.0014 & elongated & -0.89 & -2.39 \\
5.1 & $50-250$ & $0.8-0.95$ & $7.00 \mathrm{E}-05$ & round & -2.15 & -5.27 \\
5.2 & $50-150$ & $0.6-0.9$ & 0.0003 & round & -1.15 & -3.6 \\
5.3 & $50-250$ & $0.8-0.9$ & $-2.00 \mathrm{E}-06$ & round & -0.87 & -4.12 \\
5.4 & $25-150$ & $0.75-0.9$ & 0.0003 & round & -1.01 & -3.92 \\
5.5 & no data & no data & no data & no data & -1.64 & -5.03 \\
5.6 & $50-100$ & $0.75-0.95$ & 0.0013 & round & -1.89 & -6.35 \\
5.7 & $25-100$ & $0.7-0.95$ & -0.0005 & round & 0.35 & -4.01 \\
5.8 & no data & no data & no data & no data & -0.94 & -3.2 \\
5.9 & $25-175$ & $0.85-0.95$ & -0.0002 & round & -1.39 & -3.19 \\
6.0 & $50-150$ & $0.7-0.95$ & -0.0006 & round & -0.12 & -3.44 \\
6.1 & $50-125$ & $0.8-0.95$ & -0.0003 & round & -0.13 & -4.39 \\
6.2 & $25-200$ & $0.85-0.95$ & -0.0001 & round & -0.82 & -2.55 \\
6.5 & no data & no data & no data & no data & -1.53 & -5.09
\end{tabular}

each having elevations of about 2500 meters above sea level. A healthy fringing coral reef system thrived in an embayment from the Caribbean Sea that occupied the current valley in early and mid Holocene time (Taylor et al. 1985; Greer and Swart 2006). By about $5 \mathrm{ka}$, flood plain and alluvium deposits had choked the mouth of the embayment, isolating it from the $\mathrm{Ca}$ ribbean Sea and evaporating to form ancient Lago Enriquillo. The arid climate results in the lake's present base level 40 meters below sea level at the western end of the valley. Salinity of the modern waters range between $44 \%$ and $98 \%$ annually, but storm induced rainfall has contributed to seasonal decreases in salinity and higher lake levels in the past (Greer and Swart 2006).

Ostracoda that have been reported from the valley (Bold 1976, 1990a, 1990b; Mclaughlin and Bold 1991) include a marine dominated association of Trachyleberididae and Bairdidae in the normal marine patch reef and fringing reef deposits. Transitional marine to restricted-marine deposits are dominated by Loxoconcha. The restricted lagoonal and lacustrine facies are dominated by Cyprideis salebrosa (Bold 1963), C. edentata (Klie 1939), C. similis (Brady 1869), and C. mexicana (Sandberg 1964).

\section{METHODS}

\section{Sample Collection and Preparation}

The primary locality for study is a 6.5 meter stratigraphic section (text-figs. 1, 2) measured at Cañada Honda, a large and accessible gulley on the north side of Lago Enriquillo. We observed composition, textures, sedimentary structures, bedform morphology and macrofossil distributions. We recognize three primary sedimentary units where Cañada Honda was intensively sampled. The units include: Unit $1(0.0-3.25 \mathrm{~m}) \mathrm{sam}-$ pled every 0.5 meters; Unit $2(3.25-4.4 \mathrm{~m})$ sampled every 0.5 meters, and Unit 3 (Site 1C: $4.5-6.5 \mathrm{~m}$ ) sampled at $10 \mathrm{~cm}$ intervals. Two subsections of Unit 3, Site 1A, and Site 1B, were sampled at $10 \mathrm{~cm}$ intervals.
Microfossils were processed using conventional techniques outlined in Scott et al. (2001). Sediment samples were crushed with a mortar and pestle and soaked in a dilute solution of detergent and water. The samples were rinsed over a 63ìm sieve to remove clay and mud. The $>63 \mu \mathrm{m}$ sediment fraction was transferred to a Petri dish and dried in an oven at approximately $100^{\circ} \mathrm{C}$. Processed samples were dry-sieved and microfossils from the $150 \mu \mathrm{m}$ and $300 \mu \mathrm{m}$ size fractions were extracted and placed on standard microfossil slides.

\section{SEM Imaging and Pore Measurements}

Ostracodes were photographed using a variable-pressure scanning electron microscope (Hitachi S-3400N), with emphasis on creating low magnification $(\sim 300 \mathrm{x})$ images of the anterior, median and posterior regions of the external carapaces. Type $\mathrm{C}$ normal sieve pores (Puri 1974) were observed on uncoated specimens using a backscatter detector, low gas pressures ( 30-70 Pascals), and low voltages (10-15 kV). Image analysis software (Image J 1.30v: National Institutes of Health) was used to measure circularity and area of the sieve pores [Circularity = $4 \mathrm{p}\left(\right.$ area/perimeter $\left.\left.{ }^{2}\right)\right]$. We plotted the circularity values $(0=\mathrm{ir}-$ regular; $1=$ circular) against the area of the pore and generated a best fit linear trend line to establish the general slope for each specimen analyzed (text-fig. 3).

\section{Isotope Geochemistry}

Stable isotope analyses were performed on the valves of the ostracode Cyprideis salebrosa. Individual valves were weighed to $20 \mu \mathrm{g}$ per sample, soaked in deionized water and the excess residual material was removed with a sable-hair paintbrush. The specimens were roasted in vacuo at $200^{\circ} \mathrm{C}$ and analyzed using a MAT 253 mass spectrometer directly coupled to a Keil-III carbonate preparation device at the University of Saskatchewan Isotope Laboratory. Calcite isotope values are reported relative to Vienna Pee Dee Belemnite (VPDB). 

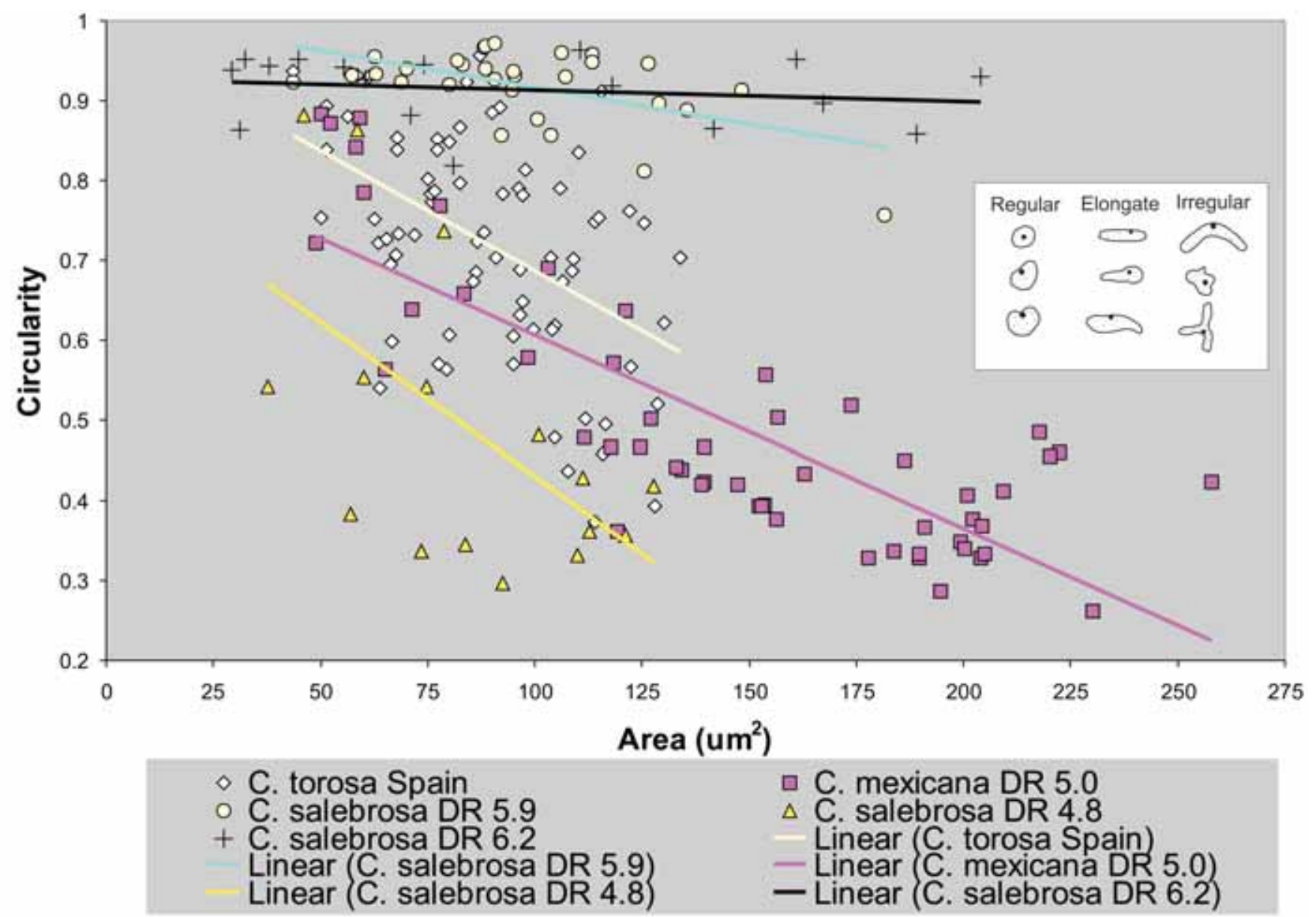

TEXT-FIGURE 3

Circularity versus area cross plots from a small population of living Cyprideis torosa collected from Alicante, Spain in 66\%o waters. Note that a steep slope $(-\mathrm{m})$ is observed from the linear trendline when the pores were likely developed in hypersaline waters of the western Mediterranean. Also included are data from representative Cyprideis spp. from the Dominican Republic (DR) from various stratigraphic heights to illustrate examples of both positive and negatively sloping trendlines that we interpret as representative of hyper and hyposalinity respectively. The inset box is an illustration of the typical circular pore shapes: round, elongate and irregular.

\section{RESULTS}

\section{Biofacies}

The Cañada Honda study site comprises a measured stratigraphic section of 6.5 meters of strata with the following three primary biofacies: (1) calcarenite with Montastraea annularis corals and stenohaline Trachyleberidae and Bairdidae ostracodes; (2) calcarenite rubble with Acropora cervicornis corals and the mesohaline ostracode Loxoconcha levis; (3) calcilutite with Tagelus plebius clams and the euryhaline ostracodes Cyprideis salebrosa, C. mexicana, $C$. similis, and $C$. edentata. Unit 3 is comprised of subsections $1 \mathrm{~A}, 1 \mathrm{~B}$, and $1 \mathrm{C}$ (text-fig. 2) that were deposited after the initial separation of the ancient lake from the Caribbean Sea at $5 \mathrm{Ka}$. This biofacies is of particular interest for pore morphometric and geochemical analyses because the hydrologically restricted lake deposits yield a history of variation in salinity. In addition to Cyprideis, marine ostracodes also are present in Unit 3, including Perisocytheridea within the $5.2-5.4 \mathrm{~m}$ interval and scarce occurrences at $5.7 \mathrm{~m}$. Nonmarine ostracodes dominate the uppermost 6.1-6.5m interval of Unit 3, including Cytheridella, Limnocythere, and Cypridopsis spp.

\section{Pore Morphometrics}

Table 4 illustrates the total number of pores measured for each stratigrahic height. Three typical pore shapes were identified on Cyprideis salebrosa: (1) multiradiate pores that yield low circularity values $(1.0=$ perfect circularity $)$ with relatively large pore areas (negative slope $=-0.0039)$; $(2)$ elongated pores characterized by low circularity values and variable sized pores (negligible slope $=0.00005$ ); and (3) round pores with circularity values that cluster slightly under 1.0 circularity with areas that are relatively small (positive slope $=0.0013$ ). The slope values for select measured specimens are illustrated in text-figure 3 to demonstrate that specimens with numerous large, irregular and elongated pores exhibit linear trend lines with negative slopes, and specimens with relatively small and round pores tend to exhibit linear trends with positive slopes. Cyprideis salebrosa exhibits variability between highly irregular pores and slightly irregular pores in the $0.0-0.5 \mathrm{~m}$ Interval I that overlies the Acropora cervicornis calcarenite (text-fig. 4). Within the 5.1-5.6m Interval II, Cyprideis salebrosa exhibits regular pores with little variability. The uppermost Interval III (5.7-5.6m) contains Cyprideis salebrosa that exhibit positive slopes (text-fig. 4). 


\section{Geochemical Analysis}

Text-figure 5 presents $\delta^{18} \mathrm{O}$ and $\delta^{13} \mathrm{C}$ values for Sites $1 \mathrm{~A}, 1 \mathrm{~B}$, and $1 \mathrm{C}$. For each sample, one adult valve was sufficient enough for analysis and all samples were excellent or good condition. Twenty-one Cyprideis salebrosa samples were analyzed from Site $1 \mathrm{~A}$. In the lower interval, $\delta^{18} \mathrm{O}$ values range between 0.8 and $-1.2 \%$ VPDB with maxima at $4.6 \mathrm{~m}$ and minima at $4.9 \mathrm{~m}$. Carbon isotope values in Interval I vary between -1.5 and $-5.0 \%$ VPDB, with maxima at $4.6 \mathrm{~m}$, and minima at $4.8 \mathrm{~m}$. Within Interval II, $\delta^{18} \mathrm{O}$ values are less variable ranging between -0.9 and $-2.1 \%$ VPDB, with maxima at $5.3 \mathrm{~m}$ and minima at $5.1 \mathrm{~m}$. Carbon isotope values range between -3.6 and $-6.3 \%$ VPDB, with maxima at $5.2 \mathrm{~m}$ and minima at $5.6 \mathrm{~m}$. Within Interval III, $\delta^{18} \mathrm{O}$ values show a pronounced negative excursion, decreasing from 0.3 to $-1.5 \%$ VPDB, with maxima occurring at $5.7 \mathrm{~m}$ and minima at $6.5 \mathrm{~m}$. Carbon isotope values decrease from -3.2 to $-5.1 \%$ o VPDB, with maxima at $5.9 \mathrm{~m}$ and the minima at $6.5 \mathrm{~m}$.

Six Cyprideis salebrosa samples were analyzed from Site 1B. $\delta^{18} \mathrm{O}$ values range from 0.8 to $-1.4 \%$ o VPDB, with maxima at $5.3 \mathrm{~m}$ and minima at $5.8 \mathrm{~m}$. $\delta^{13} \mathrm{C}$ values range from -2.4 to $-5.6 \%$, with maxima at $5.5 \mathrm{~m}$ and minima at $5.3 \mathrm{~m}$.

Thirteen Cyprideis salebrosa samples were analyzed from the 4.5-5.7m interval at Site $1 \mathrm{C} . \delta^{18} \mathrm{O}$ values range between 0.9 and $-1.7 \%$ VPDB, with maxima at $5.4 \mathrm{~m}$ and minima at $5.3 \mathrm{~m}$, while $\delta^{13} \mathrm{C}$ values range between -2.6 and $-5.2 \%$ VPDB, with maxima at $5.4 \mathrm{~m}$ and minima at $4.9 \mathrm{~m}$. Normal marine ostracodes from Unit 1 were analyzed for comparison where $\delta^{18} \mathrm{O}$ values range from 0.4 and $-0.6 \%$ VPDB and $\delta^{13} \mathrm{C}$ values range from -4.1 and $-1.8 \%$ VPDB. Freshwater ostracodes were also analyzed for comparison and $\delta^{18} \mathrm{O}$ values range from 0.0 and $-0.9 \%$ VPDB and $\delta^{13} \mathrm{C}$ values range from 0.3 and $-2.5 \%$ VPDB.

Marine and freshwater ostracodes from Cañada Honda were analyzed for environmental control. For marine control, one Tracheiliberididae, three Bairdia sp., and two Loxoconcha sp. were analyzed. $\delta^{18} \mathrm{O}$ values range between -0.6 and $0.4 \%$ o VPDB, while the $\delta^{13} \mathrm{C}$ values range between -4.5 and $-1.3 \%$ VPDB. For freshwater control, three Cytheridella sp. and three Cypridopsis sp. were analyzed. $\delta^{18} \mathrm{O}$ values range between -0.9 and $-0.0 \%$ VPDB, while the $\delta^{13} \mathrm{C}$ values range between -2.5 and $0.3 \%$ VPDB.

\section{DISCUSSION}

\section{Pore Morphometrics}

The pore morphometric results presented herein support Rosenfeld and Vesper's (1977) proposition that there is a relationship between increased abundance of irregular-shaped normal pores and salinity of the water. To confirm this, we analyzed a small population of living Cyprideis torosa collected from $60 \%$ water in Alicante, Spain. Our plots of circularity versus area yielded a negative covariance between circularity and pore size. The most positive slopes are associated with the oligohaline Tagelus plebius clam layer is consistent with the original model (Rosenfeld and Vesper 1977), and justifies our depositional model for early late Holocene marine episodes within ancient lake deposits. It is likely that the increase in ostracode pore size facilitates osmoregulation in increasingly saline water and that the irregular shapes may be a physiological response to changing and/or mixed water compositions or availability of the major cations (e.g., $\mathrm{Mg}$ and $\mathrm{Ca}$ )

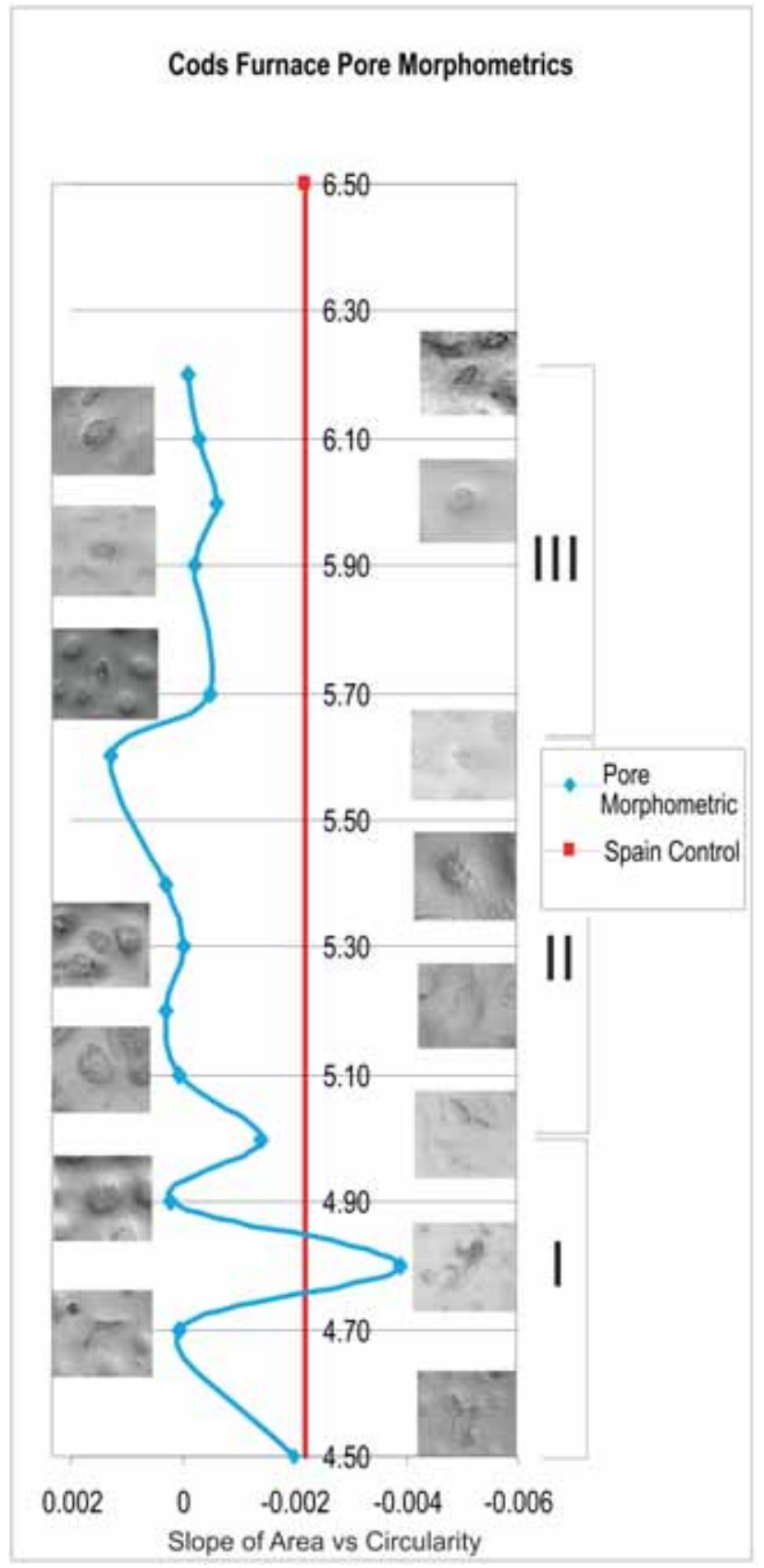

TEXT-FIGURE 4

Salinity proxy using pore morphometrics. Slope is generated from area plotted against circularity. Negative slopes are associated with irregular shaped pores whereas slopes approaching zero are associated with circular pores. Area versus circularity slope for a modern specimen of Cyprideis torosa, collected from 60\%o waters at Alicante Spain, is presented as a vertical straight line. Images of representative pores are included at each sampling point.

(see Carbonel et al. 1988). Alternatively, it may be that, although environmentally cued, the characteristics of the pores are intrinsically controlled (Peypouquet et al. 1988). Even with uncertain biological mechanisms, we regard the dramatic variations in pore shape and size as an indication for compositional changes and/or salinity in the hydrologic system that is likely linked to vacillating precipitation-evaporation budgets during the mid-to late Holocene time. 


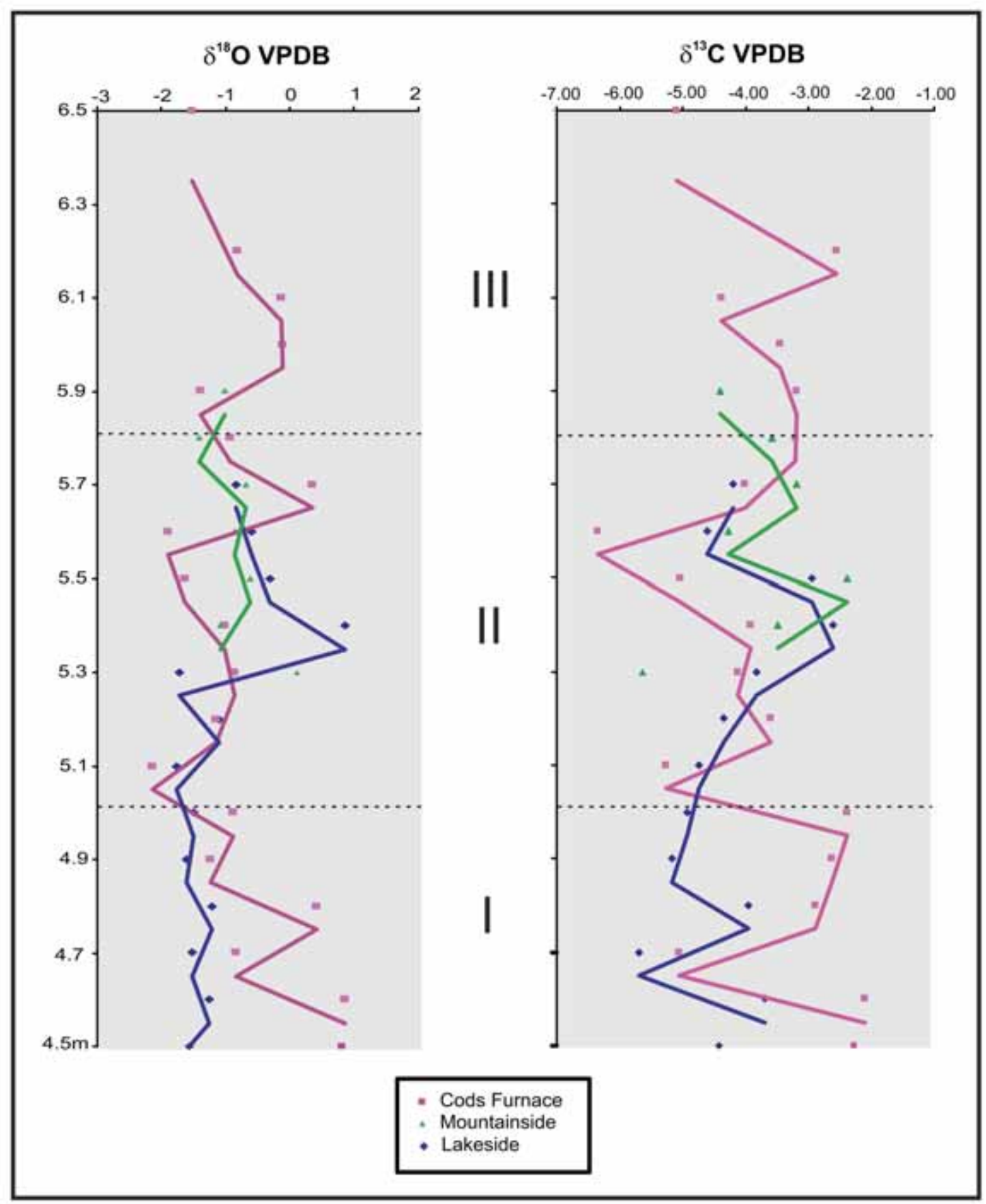

TEXT-FIGURE 5

Summary of the oxygen and carbon isotope data. The solid lines are plotted as 3-point averages.

\section{Isotope Fractionation}

Several processes influence oxygen and carbon isotope values, including precipitation trajectories, atmospheric and water temperature effects, vital effects, and precipitation and evaporation budgets (Holmes and Chivas 2002; Ito 2002; Ito et al. 2003). We attribute variation in ostracode isotope values as a combined response to changes in evaporation and precipitation (text-fig. 7) and mixing of marine and fresh waters. Similar paleohydrological models have been invoked for marginal marine deposits using the ostracode Cyprideis (e.g., Gliozzi and Mazzini 1998; Mazzini et al. 1999; Anadon et al. 2002).
Positive excursions in $\delta^{13} \mathrm{C}$ values in open marine systems are generally regarded as an indicator for enhanced productivity (Ito et al. 2003). In contrast, restricted marine water may yield relatively low $\delta^{13} \mathrm{C}$ values (Patterson and Walter 1994). Such is the case for ostracoda analyzed in Bahamian marine saline ponds where the negative carbon values were attributed to an increase in soil-derived bicarbonate from surface run-off (Dix et al. 1999). Cronin (2005) reported negative $\delta^{13} \mathrm{C}$ values from late Holocene sediments in Chesapeake Bay attributed to DIC influenced by organic matter with low $\delta^{13} \mathrm{C}$ values. Holocene coastal sediments in Tuscany, Italy, have also yielded 


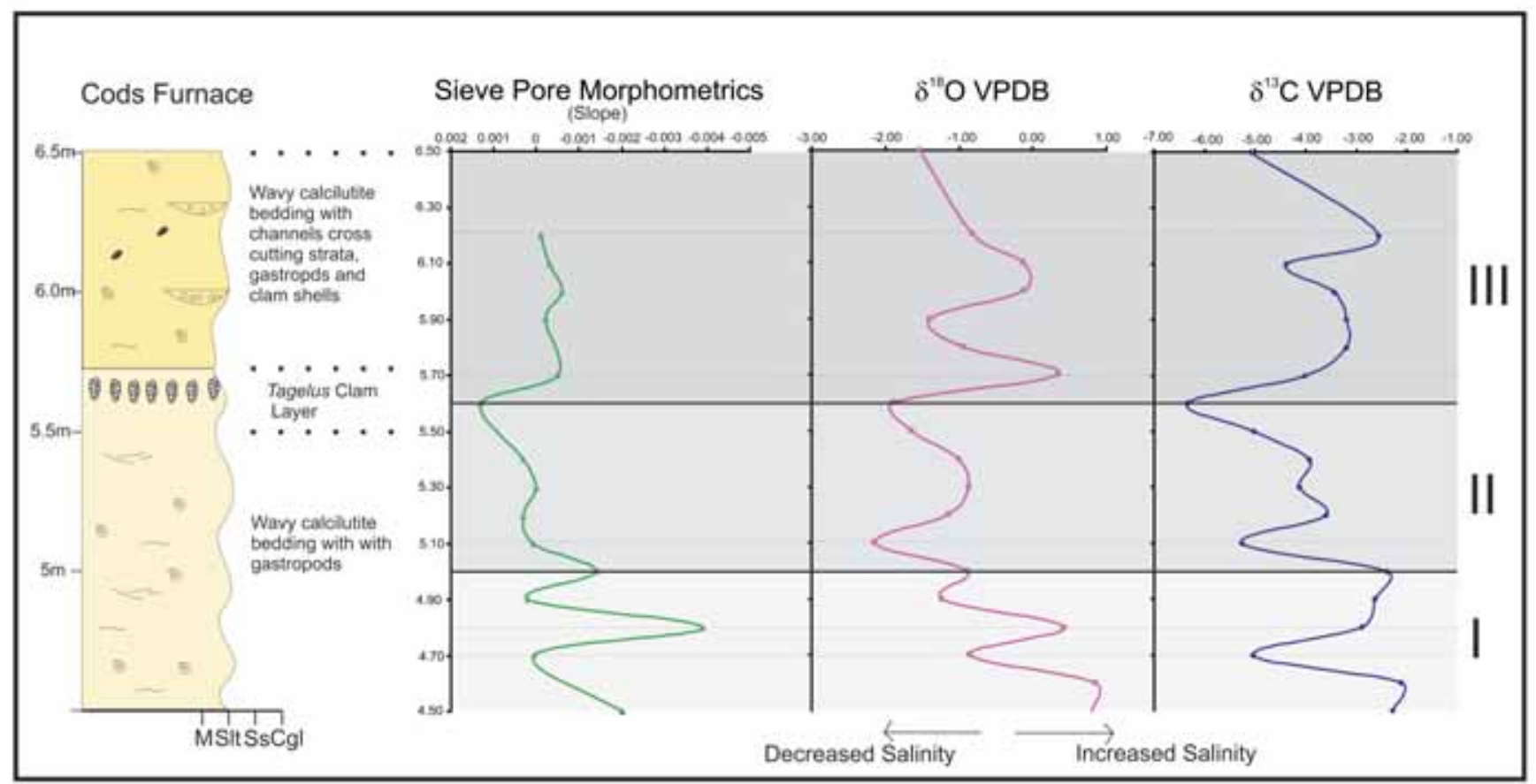

TEXT-FIGURE 6

Synthesis of lithology, pore results, $\delta^{18} \mathrm{O}$ and $\delta^{13} \mathrm{C}$ values for site $1 \mathrm{~A}$. Values to the left indicate increased salinity and values to the right indicate decreased salinity.

Ostracoda with highly variable $\delta^{13} \mathrm{C}$ values that ranged between -4.2 and $-10.35 \%$ VPDB attributed to strong evaporative effects in a shallow lagoonal setting (Mazzini et al. 1999). Given the closed nature of the Lago Enriquillo system, we interpret the positive $\delta^{13} \mathrm{C}$ values coincident with positive shifts in $\delta^{18} \mathrm{O}$ largely to record evaporative effects and DIC influenced by the Quaternary and older carbonates that characterize the watershed of the entire Enriquillo Valley (Bold 1990a). However, periodic mixing of the waters may account for some of the isotopic variation.

\section{Paleosalinity Model}

Table 2 and Figure 6 provide a synthesis of the lithologic, pore morphometric, and stable isotope geochemical analyses. We identify three temporally variable salinity intervals.

Restricted Marine Phase: Interval I (4.5-5.0m) is characterized by high shifts in all proxy indicators, suggesting that salinity was highly variable soon after the lagoon was isolated from open marine water. Thus decreasing pore size and increasing $\delta^{18} \mathrm{O}$ and $\delta^{13} \mathrm{C}$ values indicate abrupt increases in salinity are likely forced by shifts to arid climatic conditions or mixing of marine and fresh water masses (text-fig. 7). Associated mesohaline ostracodes (Tracheiliberidae, Bairdia sp., and Loxoconcha sp.) indicate periodic marine incursions at this interval.

Restricted Lagoon Phase: Interval II (5.1-5.6m) demonstrates low amplitude variation in both the pore slopes and isotopic trends and is suggestive of a steady and gradual freshening of the waters. This interval culminates with the Tagelus plebius clam horizon which is generally regarded as a low salinity, brackish marine indicator (Bold 1990a) (text-fig. 2). The freshening of the system likely resulted from increased precipitation in the watershed whereas rainwater rich with DIC derived from terrestrial vegetation contributed to the normal pores and low isotope values recorded in the ostracodes (text-fig. 7). The presence of Perissocytheridea sp. and the positive excursion of $\delta^{18} \mathrm{O}$ and $\delta^{13} \mathrm{C}$ at $5.3 \mathrm{~m}$ indicate a brief incursion of marine water.

Restricted Lacustrine Phase: Interval III (5.7-6.5m) is characterized by a change in lithology at $5.7 \mathrm{~m}$ coincident with irregular pore shape and high $\delta^{18} \mathrm{O}$ and $\delta^{13} \mathrm{C}$ values and is suggestive of increased salinity of the lake waters. The presence of Perissocytheridea sp. here likely indicates marine influence. The uppermost trend towards decreased $\delta^{18} \mathrm{O}$ and $\delta^{13} \mathrm{C}$ values and relative increased abundance of the oligohaline, largely nonmarine ostracodes Limnocythere, Cypridopsis, and Cytheridella (Bold 1990a) indicates a shift to an exclusive nonmarine fauna no later than $2.8 \mathrm{kyr}$ before present (text-fig. 6). This interval is also characterized by small alluvial channels that could be a physical manifestation of abrupt changes in baselevel that contributed to increased surficial runoff within the valley (text-fig. 6).

\section{Climate-forcing Mechanisms}

We are in favor of the model proposed by Hodell et al (1991) which invoked a northward shift in the intertropical convergence zone (ITCZ) to account for negative $\delta^{18} \mathrm{O}$ ostracode values attributed to increased humidity during the mid-to-late Holocene on Hispaniola. Comparable ITCZ models have been proposed to account for anoxia episodes in the Cariaco Basin (Haug et al 2001). Greer and Swart (2006) propose a northward migration of the ITCZ in the mid-Holocene for decadal scale variations in the regional Caribbean climate. Neff et al. (2001) also invoked latitudinal shifts in the ITCZ to explain millennial scale variability in speleothem data from Oman. For the Dominican Republic, the rainy season occurs during the summer when the ITCZ advances to its northern extent. An increased north- 

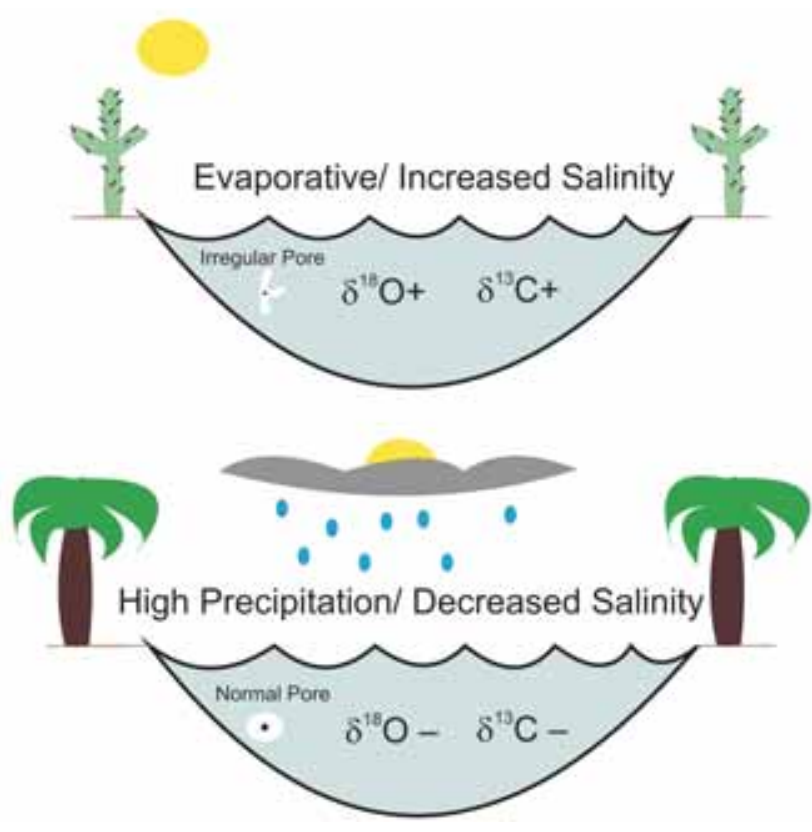

TEXT-FIGURE 7

Model illustrating times of high evaporation and high precipitation. Round pores and relatively negative oxygen and carbon isotope values are representative of high precipitation, and irregular pores and relatively positive oxygen and carbon isotope values are representative of high evaporation.

ward migration of the ITCZ would theoretically weaken easterly trade winds and displace the North Atlantic subtropical high, resulting in increased precipitation on Hispañola. Oceanic heat and moisture may have increased hurricane intensity and frequency that potentially flushed the lake system on a seasonal basis. Furthermore, the modern lake has returned to a highly evaporative condition forced by the current semi-arid climate in the Enriquillo Valley.

The positive excursions in $\delta^{18} \mathrm{O}$ and $\delta^{13} \mathrm{C}$ values associated with the marine ostracode Perissocytheridea indicate that marine waters periodically inundated the restricted lagoon. There- fore the mixing of marine and freshwater may account for some of the isotopic variation in the system, a process that is common in marginal marine environments (Anadon et al. 2002). A mechanism that could easily create such dramatic events is tectonic activity or sea level rise rate change.

The Enriquillo Valley is bounded by active faults that trend east-west across the southern part of Hispaniola (Mann et al. 1984). The area is a compressional ramp valley, where the floor is depressed by overthrusting loads of the neighboring mountains. Raised Pleistocene reefs indicate an average uplift of 0.3 mm per year over the past 130,000 years (Mann et al. 1984; Lewis et al. 1990). Moreover, earthquakes are relatively common in this region of the Caribbean and may help to explain the sudden and abrupt changes in baselevel and incursions of marine waters into the restricted lagoonal system soon after its isolation. Any minor changes in baselevel could dramatically change the drainage patterns and increase the potential for marine waters to breach the fluvial barrier to the east of the valley (text-fig. 1). The erosional surfaces at and above the Tagelus plebius horizon imply abrupt environmental changes, and the presence of conglomerates and alluvial channels is suggestive of rapid lowering of baselevel immediately followed by a minor marine incursion. A micro-tectonic event(s) could easily account for these observations or alternatively closure of the valley was influenced by climate forced autogenic fluvial processes contributed to closure of the bay mouth (e.g., Greer and Swartz 2006).

\section{CONCLUSIONS}

Increased abundances of irregular-shaped ostracode pores coincident with high $\delta^{18} \mathrm{O}$ and $\delta^{13} \mathrm{C}$ values are proxy indicators for increased hypersalinity associated with high evaporation rates that corroborate the paleosalinity model proposed by Rosenfeld and Vesper (1977). Additionally, the complex paleosalinity history for middle Holocene strata in the Enriquillo Valley of the Dominican Republic was likely forced by changes in evaporation and precipitation such that there is a distinct trend from highly evaporative basal deposits to upper, freshwater dominated deposits. Periodic incursions of marine waters also contributed to variation in the stable isotope data.

\section{PLATE 1}

Ostracoda

A Cyprideis salebrosa Bold, 1963. Right-lateral aspect juvenile valve with noding typical for oligohaline waters (Carbonel, et al. 1988).

B Cyprideis similis Brady, 1869. Left-lateral aspect of adult valve.

C Cyprideis edentata Klie 1939. Right-lateral aspect of adult carapace.

D Cyprideis mexicana Sandberg, 1964. Right-lateral aspect of adult. Image captured using 30 pascals gas pressure at 15 kilovolts in backscatter compositional mode to emphasize the multiradiate pores.

E Cyprideis torosa (Jones 1850). Left lateral aspect of an adult female. Collected from a salt pan in Alicante, Spain in waters of $60 \%$ (F. Mezquita).

F Cyprideis mexicana. Left lateral enlargement of D illustrating the irregular, multiradiate pore type C (Puri, 1974). 


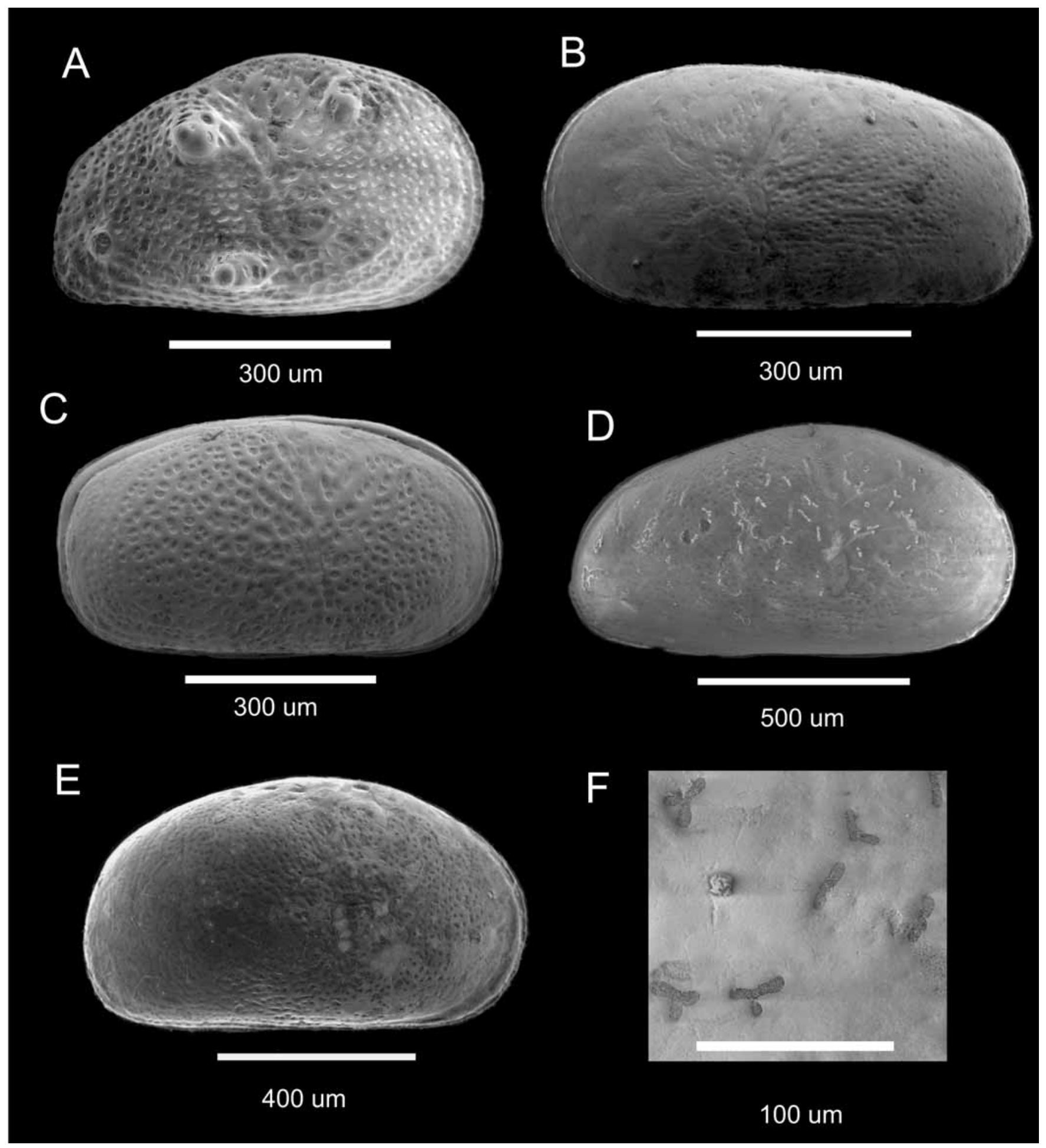


We recognize three environmental phases that recorded in the post-reefal Holocene strata at Cañada Honda in the Enriquillo Valley: a lower evaporative marine phase, a middle lagoonal phase, and an upper lacustrine phase. Incursions of marine waters punctuate the restricted lagoonal and lacustrine phases. The environmental evolution of these deposits demonstrates a complex record of climate forcing, marine-freshwater mixing, and micro-tectonic processes.

\section{ACKNOWLEDGMENTS}

This paper is the result of an honors thesis completed by PM at the University of Mary Washington (UMW). Thanks to Grant Woodell (UMW) and Charles Whipkey (UMW) who provided many useful comments to greatly improve an early version of this manuscript. The authors wish to thank financial support provided by UMW Undergraduate Research Grants and the KECK Geology Consortium. Thanks to Tim Prokopiuk in the Saskatchewan Isotope Laboratory for assistance with isotope analyses. We also wish to acknowledge NSF MRI grant 0420333. Thanks to the helpful pre-reviews provided by Lisa Park (Akron) and Steve Burns (UMass).

\section{REFERENCES}

ANADON, P., GLIOZZI, E., and MAZZINI, I., 2002. Paleoenvironmental reconstruction of marginal marine environments from combined paleoecological and geochemical analyses on ostracods. In: Holmes, J. A., and Chivas, A. R., Eds., The Ostracoda: Applications in Quaternary Research, 227-247. Geophysical Monograph Series 131. Washington DC: American Geophysical Union.

BOLD, W.A., VAN DEN, 1963. Upper Miocene and Pliocene Ostracoda of Trinidad. Micropaleontology 9(4): 361-424.

1976, Distribution of species of the tribe Cyprideidini (Ostracoda, Cytherideidea) in the Neogene of the Caribbean, Micropaleontology 22(1):1-43.

1990a. Late Holocene Ostracoda in and around Lake Enriquillo, Dominican Republic. In: Larue, D.K., Draper, G., Eds., Transactions of the $12^{\text {th }}$ Caribbean Geological Conference, St Croix, U.S.V.I., 163-189. Miami Geological Society.

, 1990b. Stratigraphical distribution of fresh and brackish water Ostracoda in the late Neogene of Hispaniola. In Whatley, R.C., Maybury, C., Eds., Ostracoda and Global Events, 221-232. International Symposium on Ostracoda 10. London: Chapman and Hall.

BOOMER, I., 2002. Environmental applications of marine and freshwater Ostracoda. In: Haslett, S. K., Ed., Quaternary Environmental Micropalaeontology, p. 155-138.

BRADY, G.S., 1869. Description of ostracoda. In: de Folin et Perier, Eds., Les Fonds de la Mer, 1: 113-176.

CARBONNEL, G., 1983. Morphometrie et hypersalinite chez Cyprideis torosa (Jones) (Ostracoda, actuel) dans les salines de santa-pola (Alicante, Espagne). Sci. Geol., Strasbourg, Bull. 26, 4: 211-219.

CARBONNEL, G. and HAJ-CHAHINE, T, 2002. Paleosalinite et microstructures chez Cyprideis pannonica (Mehes, 1908) ostracode, Tortonien. Archs Sci. Geneve, 55: 21-32.

CARBONEL, P., COLIN, J.-P., DANIELOPOL, D. L., LOFFLER, H., and NEUSTRUEVA, I., 1988. Paleoecology of limnic ostracodes: A review of some major topics: Palaeogeography, Palaeoclimatology, Palaeoecology, 62: 413-461.

CRONIN, T.M., THUNELL, R., DWYER, G.S., SAENGER, C., MANN, M.E., VANN, C. and SEAL II, R.R., 2005. Multiproxy evi- dence of Holocene climate variability from estuarine sediments, eastern North America. Paleoceanography, 20: 1-21.

DIEFENDORF, A.F., PATTERSON, W.P., MULLINS, H.T., TIBERT, N.E., and MARTINI, A., 2005. Evidence for high-frequency Late Glacial to mid-Holocene (16,800 to 5,500 calendar years BP) climate variability from oxygen isotope values of Lough Inchiquin, Ireland. Quaternary Research, 65: 78-86.

DIX, G.R., PATTERSON, R.T, and PARK, L.E., 1999. Marine saline ponds as sedimentary archives of late Holocene climate and sea-level variation along a carbonate platform margin: Lee Stocking Island, Bahamas. Palaeogeography, Palaeoclimatology, Palaeoecology, 150: 223-246.

GLIOZZI, E. and MAZZINI, I., 1998. Palaeoenvironmental analysis of early Pleistocene brackish marshes in the Rieti and Tiberino intrapenninic basins (Latium and Umbria, Italy) using ostracods (Crustacea). Palaeogeography, Palaeoclimatology, Palaeoecology, 140: $325-333$.

GREER, L. and SWART, P.K., 2006. Decadal cyclicity of mid-Holocene tropical storms as mediated by tropical Atlantic sea surface temperatures: evidence from Dominican coral proxies. Palaeoceanography, 21: P2020.

HAUG, G.H., HUGHEN, K.A., SIGMAN, D.M., PETERSON, L.C., and ROHL, U., 2001. Southward migration of intertropical convergence zone through the Holocene. Science, 293: 1304-1308.

HOLMES, J.A., and CHIVAS, A.R., 2002. Ostracod Shell ChemistryOverview, The Ostracoda: Applications in Quaternary Research, 185-204. Geophysical Monograph Series 131. Washington DC: American Geophysical Union.

HODELL, D. A., J.H. CURTIS, G.A. JONES, A. HIGUERA-GUNDY, M. BRENNER, M.W. BINFORD, and K.T. DORSEY, 1991. Reconstruction of Caribbean climate change over the past 10,500 years. Nature, 352: 790-793.

ITO, E., 2002. $\mathrm{Mg} / \mathrm{Ca} / \mathrm{Sr} / \mathrm{Ca}, \delta^{18} \mathrm{O}$, and $\delta^{13} \mathrm{C}$ Chemistry of Quaternary Lacustrine Ostracode Shells from the North American continental Interior. In: Holmes, J. A., and Chivas, A. R., Eds., The Ostracoda, Applications in Quaternary Research, 267-278. Geophysical Monograph Series 131, American Geophysical Union, Washington DC.

ITO, E., DE DECKKER, P., and EGGINS, M., 2003. Ostracodes and Their Shell Chemistry: Implications for Paleohydrologic and Paleoclimatologic Applications. In:Park, L.E., Smith, A.J., Eds., Bridging the Gap, Trends in the Ostracode Biological and Geological Sciences, 119-152. The Paleontological Society Papers, 9: .

JONES, T.R., 1850. Descriptions of the entomostraca of the Pleistocene beds of Newbury, Copford, Clacton, and Grays. Annals of the. Magazine of Natural History, London, Series 1, 2(31): 27.

KLIE, W., 1939. Ostracoden aus den marinen Salinen von Bonaire, Curacao und Aruba. Capita Zoologica, 8(42): 1-19.

LEWIS, J.F., DRAPER, G., BOWIN C., BOURDON, L., MAURRASSE, and NAGLE, F., 1990. Hispaniola. In: Dengo, G. and Case, J.E., Eds., The Geology of North America; The Caribbean Region, 94-112. Geological Society of America, The Decade of North American Geology Series, H.

MANN, P., TAYLOR, F.W., BURKE, K., and KULSTAD, R., 1984. Subaerially exposed Holocene coral reef, Enriquillo Valley, Dominican Republic. Geological Society of America Bulletin, 95: 1084-1092. 
MAZZINI, I., ANADON, P., BARBIERI, M., CASTORINA, F., FERRELI, L., GLIOZZI, E., MOLA, M., and VITTORI, E., 1999. Late Quaternary sea-level changes along the Tyrrehnian coast near Orbetello (Tuscany, central Italy): Palaeoenvironmental reconstruction using ostracods. Marine Micropaleontology, 37: 289-311.

MCLAUGHLIN, P.P., BOLD, W.A., van den, and MANN, P., 1991. Geology of the Azua and Enriquillo basins, Dominican Republic; 1, Neogene lithofacies, biostratigraphy, biofacies, and paleogeography, 337-366. Geological Society of America, special paper 262.

NEFF, U., BURNS, S.J., MANGINI, A., MUDELSEE, M., FLEITMANN, D., and MATTER, A., 2001. Strong coherence between solar variability and the monsoon in Oman between 9 and 6 kyr ago: Nature, 411: 290-293.

PATTERSON, W.P., and WALTER, L.M., 1994. Depletion of ${ }^{13} \mathrm{C}$ in seawater $\mathrm{CO}_{2}$ on modern carbonate platforms: significance for the carbon isotopic record of carbonates. Geology, 22: 885-888.

PEYPOUQUET, J.P., CARBONEL, P., DUCASSE, O., TOELDERER-FARMER, M., and LETE, C., 1988. Environmentally-cued polymorphism of ostracods; a theoretical and practical approach; a contribution to geology and to the understanding of ostracod evolution. In Hanai, T., Ikeya, N., Ishizaki, K., Eds., Evolutionary biology of Ostracoda; its fundamentals and applications, 1003-1019. Devel- opments in Palaeontology and Stratigraphy 11. Amsterdam: Elsevier.

PURI, H.S., 1974. Normal Pores and the Phylogeny of Ostracoda. Geoscience and Man, 6: 137-151.

ROSENFELD, A., and VESPER, B., 1977. The variability of the sieve-pores in Cyprideis torosa (Jones 1850), recent and fossil, as an indicator for salinity and paleosalinity. In: Loffler, $\mathrm{H}$ and Danielpol, D., eds., Aspects of Ecology and Zoogeography of Recent and Fossil Ostracoda, 55-66. The Hague: Junk.

SANDBERG, P.A., 1964. The ostracode genus Cyprideis in the Americas. Acta Universitata Stockholmiensis. Stockholm Contributions in Geology, 12: 1-178.

SCOTT, D.B., MEDIOLI, F.S., and SCHAFER, C.T., 2001. Monitoring in coastal environments using foraminifera and Thecamoebian indicators. New York: Cambridge University Press, 167 p.

TAYLOR, F.W., MANN, P., VALASTRO S., and BURKE K., 1985. Stratigraphy and radiocarbon chronology of subaerially exposed Holocene coral reef, Dominican Republic. Journal of Geology, 93: 311-332.

Manuscript received December 23, 2006

Manuscript accepted August 1, 2007 
